
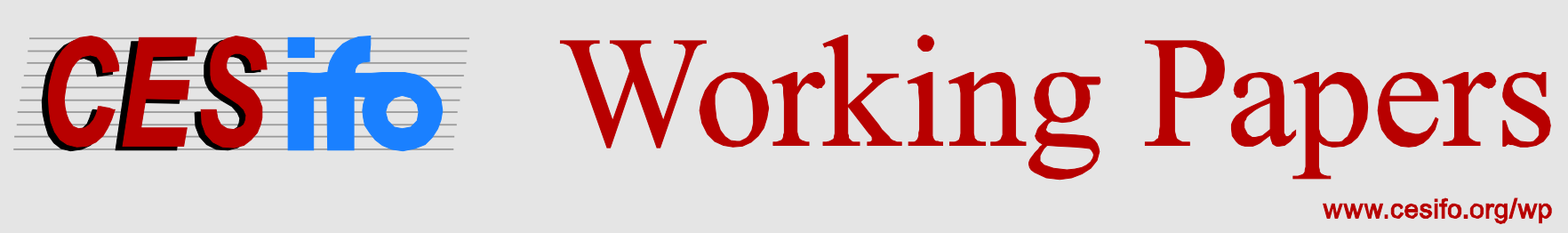

\title{
Petroleum Taxation and Investment Behaviour
}

\author{
Petter Osmundsen \\ Magne Emhjellen \\ Thore Johnsen \\ Alexander Kemp \\ Christian Riis
}

\section{CESIFO WORKING PAPER NO. 5046 \\ CATEgORY 1: Public FinANCE \\ OCTOBER 2014}

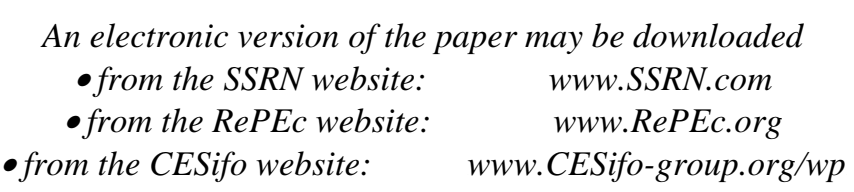




\title{
Petroleum Taxation and Investment Behaviour
}

\begin{abstract}
Petroleum administration can be regarded as a principal-agent problem. The government allocates exploration and production rights to petroleum companies on behalf of the population. The government is the principal and the companies are agents. With the aim of capturing revenue for the state, the government devises a petroleum tax system which takes account of the investment decisions made by the companies, while acknowledging for the fact that the companies may report strategically to the government. An important issue is how tax deductions are to be treated in investment analysis. A discrepancy arises here between assumptions made in some areas of tax theory and the actual investment analyses conducted by the companies. Tax theory has given rise to discussion and controversial tax proposals for the petroleum sector in Norway, Denmark and Australia. It led, for example, to reductions in tax-related depreciation for the Norwegian petroleum industry in May 2013. The article reviews this tax debate and analyses the implications of basing tax design on counter-factual investment behaviour.
\end{abstract}

JEL-Code: L710, F210, G020, H210, H250, H320, M210.

Keywords: petroleum taxation, tax design, valuation, corporate behaviour.

Petter Osmundsen

University of Stavanger / Norway

Petter.Osmundsen@uis.no

Thore Johnsen

Norwegian School of Economics

thore.johnsen@nhh.no
Magne Emhjellen

Petoro AS / Norway

magne.emhjellen@petoro.no

\author{
Alexander Kemp \\ University of Aberdeen / UK \\ a.g.kemp@abdn.ac.uk
}

\author{
Christian Riis \\ Norwegian Business School \\ christian.riis@bi.no
}

We thank Norwegian Research Council (Petrosam 2) for financial support. 


\section{Introduction}

The government allocates exploration and production rights to petroleum companies on behalf of the population, acting as the principal with the companies as agents. Capturing revenue for the state is the principal object. Efforts are made to devise a neutral tax system - in other words, one which ensures that the companies will wish to implement all profitable on a pre-tax basis projects and drop all unprofitable ones. This is achieved when the net present value (NPV) after tax is positive if - and only if - the NPV before tax is also positive. Note that this implicitly assumes parity between socioeconomic and commercial profitability.

While the government seeks to maximise its tax income over time, it must take account of the fact that companies set specific required rates of return for their activities. This can formalised as a participation constraint. See Osmundsen (2005). A key consideration here is the way companies make their investment decisions. We also appear to be pretty much in agreement with current decision methods in the companies. The latter apply the traditional NPV method and have relatively substantial rate of return requirements including minimum NPV/I ratios. Tax deductions are treated as other cost elements. See, for example, Brealey et al (2008):

Depreciation tax shields contribute to project cash flow, but they are not valued separately; they are just folded into project cash flows along with dozens, or hundreds, of other specific inflows and outflows. The project's opportunity cost of capital reflects the average risk of the resulting aggregate.

As in all principal-agent theory, the agent may have incentives to report strategically. Where conventional NPV analyses are concerned, the companies may have private information on the required rate of return and can in principle achieve an information rent through strategic reporting (excess reporting of the required rate of return). We can also conceive a game over the information rent related to the choice of decision method.

Where the petroleum sector is concerned, the Norwegian government has developed a fairly extensive administrative system, and civil servants are in close touch with the industry - in part through participation at licence meetings. They gather information on actual decision processes, and this knowledge is supplemented by insights from former company employees. Actual required rates of return and decision methods can also be deduced from an analysis of decisions taken (revealed preferences). Thus, the information problem is limited.

Taxation is placed in a broader framework as part of the application of principal-agent theory to the petroleum sector. See Osmundsen (2005). We study literature in the field of public sector economics 
which argues in favour of partial discounted cash flows, where tax-related depreciation has a different discount rate than other cash flows. See, for example, Fane (1987). A typical feature of this literature is that it does not build on empirical facts, but merely assumes that companies regard tax-related depreciation as riskless. We compare this with empirical work on petroleum taxation, including Johnston (2008). Furthermore, we compare it with studies of the actual investment behaviour by companies, including Summers (1987), Boston Consulting Group (2007) and Brealey et al (2008). We look at the effect of tax systems on various components of company decisions. The question is not only whether to invest, but also how the investment is dimensioned. See Osmundsen (2013). We analyse implications of different types of tax-related depreciation schemes by using model oil and gas fields.

\section{Tax design}

Governments seek to maximise their tax income over time, but must take account of the fact that companies set specific required rates of return for their activities. This can be formalised as a participation constraint. Whereas the petroleum resources are immobile, the competent oil companies are highly mobile. They typically have projects in many countries and there is competition over investments and other scarce inputs. A key consideration here is the way companies make their investment decisions. They apply the traditional NPV method and have relatively substantial rate of return requirements. Tax deductions are treated in the same way as other cash flow elements. This must be taken into account if the aim is a neutral tax system - in other words, one which does not reduce value creation by distorting company investment behaviour.

Cash flow tax is a reference case for a non-distorting tax system. It reduces the size of cash flows and will accordingly cause no distortion to investment decisions - a project which has a positive/negative NPV before tax will also have a positive/negative NPV after tax. Tax-related depreciation is a recurring issue in petroleum tax design. Permitting investment costs to be deducted in the year they are incurred will be in accordance with a cash flow tax. This is the case for exploration costs in both the Norwegian and British petroleum tax regimes. Tax-related depreciation is spread over several years in many countries. In Norway, for example, the maximum depreciation rate for development costs is 16.67 per cent per year. The NPV of tax depreciation is accordingly lower than the development cost, and the investment incentives may be too weak - underinvestment is likely.

To compensate for the NPV loss from delayed tax depreciation in Norway's petroleum tax system, a tax-free allowance or uplift is granted at a certain percentage per annum over a given number of years. This uplift is computed on the basis of the original capitalised cost of offshore production installations. A similar system applies in Australia, for example. Investment neutrality is maintained when the uplift 
has been set so that it becomes a matter of indifference to the oil companies whether investment can be deducted in the year it is made or they receive the sum of tax deductions over a given number of years plus uplift - provided they are certain to be in a tax paying position. The uplift thereby compensates for the NPV loss of delayed tax depreciation. When setting the uplift, the government accordingly needs to ascertain the rate of return required by the companies (the discount factor). This has become a recurrent topic for debate between the Norwegian government and the companies, especially after a controversial change to the uplift in May 2013 cut its annual rate from 7.5 per cent over four years to 5.5 per cent also over four years.

Norway's Ministry of Finance has assumed that the companies use partial discounted cash flow analysis and, if they utilise a simpler method which may yield a different project assessment, this will be of little significance for the Ministry. It departs here from principal-agent theory, which precisely seeks to clarify and build on the actual decision criteria used by the companies. This poses challenges in that socioeconomically profitable projects might now be dropped. We should add here that this comes up at a very unfortunate time, the oil companies are in a period of capital rationing and critical upgrades are required on a number of the mature fields on the Norwegian continental shelf (NCS) if large volumes of oil are not to be lost (Osmundsen 2013). The socioeconomic losses could be very substantial.

Assuming contra-factual behaviour in the field of regulation and taxation is unusual. Under the previous government, the Ministry (2013) claimed that the oil companies apply changing and irrational decision criteria, and that the tax system must therefore build on theory. When reality does not accord with theory, it must yield. The terrain must be compelled to agree with the map. The Ministry appears to believe that multinational oil companies - some of the world's largest, most sophisticated and profitable enterprises - are not capable of safeguarding their assets. That puts it in conflict not only with reality but also with the normative theory it cites - which builds precisely on the view that companies optimise their assets.

The Ministry bases its views about petroleum taxation and partial discounted cash flows on financial theory about value additivity. This states that the value of an investment project can be calculated in principle as the sum of the values of partial discounted cash flows, each discounted by an associated risk-adjusted requirement. Osmundsen and Johnsen (2013) explain why this method, with separate discounting of operational flows and tax deductions from depreciation, uplift and interest charges respectively, is unusable in practice. Instead, companies on the NCS and elsewhere in the world use a simple decision model with collective discounting of new cash flows, not least because this is to be communicated to, understood by and applied in decentralised units of large multinational companies 
with the participation of employees who have various types of education. ${ }^{2}$ An equally important consideration is that market values or risk-adjusted discount rates do not exist in practice for the various partial flows. Implementing the Ministry’s approach with value additivity, for example, would require access to the market value of future tax deductions on the NCS at different times. This does not exist. Equity interests and companies change hands from time to time on the NCS, but it is not possible for a third party to gain an insight into the figures underlying these transactions. Nor can the value of the actual tax deductions be isolated. The Ministry quite simply assumes that the oil companies perceive tax deductions on the NCS as secure - despite two changes in uplift and the fact that the method calls for a further tightening in the tax regime. Nor are the investment costs which will provide the basis for the tax deductions normally known at the time the analysis is conducted, and can involve substantial - including business cycle - risk with a long investment period.

It is otherwise almost impossible to determine an accurate risk-adjusted discount rate for residual discounted cash flows in partial discounted cash flow analyses, which makes consistent decision choices difficult. In any event, the Ministry view does not produce results in the multiperiod investments models which characterise virtually all petroleum projects.

We have provided some of the grounds here for not using partial discounted cash flow analysis. No indications exist to our knowledge that this analysis method is being adopted by oil companies or enterprises in other sectors. In the debate in the Norwegian press, we have challenged the Ministry to name one company on the NCS which makes systematic use of this method when reaching development decisions, and have received no answer.

Nor have we received a response to our request that the Ministry names a sanctioned project on the NCS which was regarded as socioeconomically unprofitable when the decision was taken. In other words, the empirical basis for the tax change does not exist.

The Ministry maintains that the oil companies are unable to maximise their asset values, and uses this as an argument for reducing uplift on the NCS. This is apparently intended to encourage the companies to change their investment policy. Multinational oil companies operate with a common investment model for their global activities (adjusted for country risk) in order to ensure consistency. The idea that ExxonMobil or other companies would alter their investment model in response to changes in Norwegian petroleum taxation seems far-fetched. It also runs counter to the established division of responsibility between the companies and the state.

\footnotetext{
${ }^{2}$ A widespread perception is that the main challenges related to precision in investment analyses lie rather in quality assurance of estimated cash flows and the structuring of decision trees. Transaction cost theory can be utilised if theoretical justifications are required for simple decision models.
} 
If the Ministry really believes that the companies, with their outdated theories, are unable to take care of the commercial aspects of their projects, a discrepancy would arise between commercial and socioeconomic considerations. We must then return to the starting point, with the desire for neutrality. This would no longer be optimal if the preferred approaches of the companies and the government diverge. A logical implication of this is that we want a distorting tax regime which incentivises the companies to adjust their investment profile in the desired direction. Should one first open up for capturing supplementary socioeconomic value, many arguments exist that a number of socioeconomically viable projects on the NCS are failing to be realised - in part because the government operates with substantially lower required rates of return than the companies and because positive spin-offs offered for nearby fields by a project are often not incentivised by the licensees making the investment decision. See Osmundsen (2013).

\section{Calculation errors}

The Ministry (2013) confirms that it believes neutrality is achieved at an overall uplift of two per cent, compared with today's 22 per cent. It is difficult to understand this other than that a further dramatic tightening of petroleum taxation was contemplated. Norwegian Official Report (NOU) 2000:18 proposed two per cent. With such a low uplift, many of the projects on the NCS with a high socioeconomic value would be shelved. The logic underlying the Ministry's tax change is odd. It creates a very damaging and completely unacceptable uncertainty over future Norwegian petroleum taxation, while justifying the change on the grounds that Norwegian petroleum taxation is completely secure! Transitional arrangements of fixed duration do not adequately address this. All exploration decisions take some view of tax on future investment, so arguments that this has not been given a retroactive effect do not hold water. Major investments will also come late in the producing life of those projects affected by the changes. Expectations of future tax levels also underlie decisions on building up activity in a country.

In an attempt to understand the Ministry’s viewpoint, we have sought to work through its calculations. Even with inaccurate assumptions on risk-free tax deduction, our calculations are unable to support the Ministry’s tightening of the tax system. The Ministry (2013) makes further unrealistic behavioural assumptions.

The key issue is how the required rate of return for the residual discounted cash flow should be adjusted when presumed secure tax deductions are removed. Risk has now increased for the residual flow, and an adjustment must be made for this. The Ministry appears to argue against such an adjustment, but comes into conflict here with capital asset pricing and value additivity - that the sum of the weighted average of the various betas of the partial discounted cash flows must equal the net 
after tax cashflow beta. An unrealistic and undocumented assumption is that companies regard the tax deductions as wholly secure, and that Norwegian tax deductions are valued in a completely different way than in other producer countries. On the other hand, the Ministry (2013) makes a correction for increased risk in the residual discounted cash flow - but not in the way the companies would do it. No formula permits a simple calculation of the necessary discount rate for the residual discounted cash flow, which precisely represents one reason why this method is not used. Unlike the NPV method, the textbooks do not provide a procedure. The Ministry (2013) is remote from the individual company's reality:

To avoid confusions arising from distortions in the current tax system, it is crucial that the upward adjustment is made by comparing two neutral tax systems. The Ministry of Finance does this by comparing a petroleum tax in which the special tax component is cash-flow based and an accrued special tax with the same NPV from the tax deductions. Moreover, both options are based on an ordinary corporate tax with financially accurate depreciation. The results of such comparisons form the basis for the required rate of return for the residual uncertain discounted cash flow we have used in the calculation example.

We would note that investment on the NCS is made by the companies. Should they seek to establish a partial discounted cash flow analysis, there is no reason to believe they would make such adjustments. They would undoubtedly start from the existing tax regime. A fascinating type of logic is involved here. The companies are meant to adjust for the difference between the present tax system and a substantially stricter regime defined as neutral by the Ministry, while assuming that future tax deductions are completely secure.

Many publications have been cited during this debate in support of the tax tightening. These include Fane (1987), who appears to be representative of this branch of taxation theory. This article concludes that, if the companies can be sure of receiving the deductions, they will be able to calculate their NPV at an interest-free rate. Taking a completely overarching approach to public sector economics, the article actually says nothing about the practical shaping of uplift. It is pitched at an entirely general theoretical level which assumes perfect markets for all types of cash flow, so that simple arbitrage principles can be applied. It also builds on a strong assumption that the companies can regard the tax deductions as completely secure, which is not the case here. What comes as a surprise is that none of these articles discuss the practical problems associated with partial discounted cash flows. This might be defensible in general articles, but would be a wholly unacceptable omission in the practical design of an actual tax system. If the NPV of the "secure" tax deductions increases, the NPV of the residual discounted cash flow must also be amended to ensure that the project NPV is equal so that the value additivity is maintained (the sum of partial discounted cash flows must relate to the total NPV. See the appendix). 
The intuition underlying the upgrade of the required rate of return for the residual discounted cash flow is as follows. Oil companies are listed on the stock exchange. Stock market data can be used to calculate the systematic commercial risk for the companies, designated as their commercial beta value. When valuing a development project, a suitable average of these values is used to determine the risk supplement in the project's required rate of return. Since a development project can usually be expected to have a risk greater than the overall risk for an integrated oil company, calculating the average beta value will often utilise a higher weighting of these values, those of upstream companies. The required rate of return will thereby reflect the alternative rates of return required by the investors for investments with a level of risk corresponding to that of the project. This required return will be used to discount the project's net after tax cash flows.

Tax deductions can normally be considered to have a rather lower beta risk than the residual discounted cash flow, but are not - as the Ministry asserts - risk-free. They can therefore be discounted at a rather lower rate than the required rate of return for the project. Since the residual discounted cash flow will be riskier than the net project risk, it must be discounted at a correspondingly higher rate. The sum of calculated values for the two cash flows must in principle be equal to the value calculated above by discounting the net cash flow with the project's required rate of return. A fundamental requirement for the partial discounted cash flow analysis is that the weighted sum of betas for the partial discounted cash flows must be equal to the beta for the total project. The Ministry's approach would breach this condition.

The Ministry's alternative method is unusable because it assumes that the oil companies possess information which is actually unavailable - namely the required rates of return for each of the two cash flows. These cash flows are not traded in the market and cannot in reality be derived from the stock market pricing of oil company shares, either. The Ministry makes assumptions which eliminate this problem. It assumes that tax deductions are risk-free and can be discounted with a risk-free rate, and that the residual discounted cash flow's beta risk can be calculated in some way or another without explaining how for a realistic project. Both errors involve an over-assessment of the project's value.

The principle of value additivity means that another project value cannot suddenly be obtained because partial cash flow discounting is used. If partial cash flow discounting is used in the belief, as held by the Ministry, that the NPV of a cash flow can be found with a risk-free required rate of return, no method exists for finding the required rate for the residual discounted cash flow. Should only one other cash flow be involved, an implicit discount rate can be found for this on the basis that the project will have the same NPV (Emhjellen and Alaouze, 2002). However, what represents a natural division of net cash flow after tax is not obvious. See the appendix for an example which addresses this issue. 


\section{Model field}

A deeper understanding of the way the tax system actually functions cannot be obtained without analysing model fields. Under the previous government, the Ministry (2013) confined itself to a stylised calculation example where all investment occurred in a single period. An important difference with model fields is that they pick up the effect of project investment being spread over a number of years, and incorporate the interaction between income and costs - including whether new companies on the NCS are liable for tax.

We analyse a model field with medium profitability. See the appendix. Total production is 78 million standard cubic metres (scm) or 490 million barrels over 28 years, while overall investment is USD 15.7 billion over 10 years. Lengthy investment periods are normal. Drilling is investment, and can take place both before and after installations have been put in place. The project itself will extend over several years, and take even longer if development is phased. We have used field data representative of new discoveries in the Barents Sea. This type of bridgehead investment opens up new areas and could have substantial option value. The latter is greater for the government, because it takes account of the effect for all nearby fields. We perform calculations for companies fully liable for tax.

The starting point for tax design is neutrality - in other words, the internal rate of return is the same before and after tax. Norway's petroleum tax regime has always assumed neutrality. Uplift compensates the companies for not being able to use direct expensing, and is set on the basis of a specified reference rate of return. Above that level, the return is lower after tax than before. Reducing uplift implies that the reference rate of return also goes down, so that the problem increases. In addition, a larger proportion of marginal projects at the NCS make the distortion more serious over time.

The model project shows that the Norwegian tax regime makes it possible and probable that fields with high socioeconomic profitability fail to be realised. With a price expectation of USD 90 per barrel (real), the project yields a NPV after tax of USD 769 billion and an internal rate of return of 11.3 per cent. Tax represents 81 per cent of the NPV before tax (given equal, 9\% discount rate). The internal rate of return before tax is 15.3 per cent. With cash-flow tax, the internal rate of return would also be 15.3 per cent after tax. The after tax IRR and before tax IRR distortion is even greater for companies not liable for tax. Because interest rates on losses carried forward are low, a company not liable for tax will have an internal rate of return substantially below 11.3 per cent.

Post-tax profitability in this case may be high enough for the project to be sanctioned. But despite a positive NPV after tax, it must compete for funds in the international portfolios of the companies. The tax regime is distorting, and gives incentives for underinvestment. A project with an NPV of USD 
4.08 billion before tax at a required rate of return of nine per cent, or USD 10.7 billion at the government's four per cent rate of return requirement, risks being shelved. Taxation is the reason.

Assuming that the company is liable for tax, but that uplift is reduced to an overall two per cent, the internal rate of return after tax is only 8.2 per cent. The present value of tax now accounts for more than 100 per cent of the NPV before tax. The companies would reject a project which has a NPV of USD 10.7 billion at the government's required rate of return.

The model project is also relevant for improved oil recovery on marginal fields, which the government wants to promote. Tax could be a real obstacle to such projects. As we have shown, tax distortion represents a problem even for projects of medium profitability. The companies could then have an even bigger incentive to concentrate on less investment-intensive projects which take only the most profitable part of the oil.

\section{Expensing of investment costs}

The Ministry cites publications on public sector economics which recommend a risk-free rate for discounting tax deductions. With one exception, these have the weakness that they do not investigate empirically the assumption that such deductions are secure - which is no more than a hypothesis. ${ }^{3}$ The exception is Summers (1987). He conducted a survey of the 200 largest US companies, and found that they do not utilise partial cash flow discounting. They rely on the traditional NPV method, and also utilise a very high discount rate for tax-related depreciation. Similar and more updated surveys exist for the oil industry - the companies discount the whole cash flow collectively at a high rate. ${ }^{4}$ Summers seeks to explain the divergence from theory as a result of implementation problems or because company shareholders do not make such adjustments. Given this insight, he argues that a tax system based on partial cash flow discounting can produce underinvestment and is particularly dubious for projects with a high level of investment over a long period. He reasons that governments weigh present revenue against future income on the basis of borrowing costs. Since the companies use a substantially higher discount rate, he concludes that governments would win by introducing accelerated depreciation. Summers is in accord with principal-agent theory. The government must maximise the socioeconomic profit from the sector given the companies' actual approach. ${ }^{5}$

\footnotetext{
${ }^{3}$ In the global petroleum industry, where tax changes are frequent and tax rises on increased prices are more readily implemented than cuts on reduced prices, this is a long way from reality. See Johnston (2008).

${ }^{4}$ See, for example, Boston Consulting Group (2007).

${ }^{5}$ Osmundsen (2005).
} 
Theory and practice can be reconciled through the adoption of direct expensing or 100\% first-year allowance as in the UK. Uplift is not required in that case. The necessary calm can then be established on the petroleum tax issue.

\section{What lessons from UK and Australia?}

It is instructive to consider whether the petroleum tax systems of other countries shed light on the issues. The UK and Australia offer relevant comparisons. In the UK the Petroleum Revenue Tax (PRT) introduced in 1975 has some features in common with the resource rent tax as originally conceived (see Garnaut and Clunies Ross 1975 and 1983). Thus the PRT is levied on a field cash flow basis and thus $100 \%$ first-year allowances with an uplift provision as a rough proxy for the necessary return on capital investment and as a substitute for the non-deductibility of loan interest. The concept has worked reasonably efficiently though changes have been made to the size of the uplift allowance.

In 1993 PRT was abolished for new fields, but in 2002 a new Supplementary Charge (to corporation tax) was introduced initially at $10 \%$, then in 2006 at $20 \%$ and in 2011 at $32 \%$. In recognition of this extra tax and the non-deductibility of loan interest for the new imposition $100 \%$ first-year allowances were introduced for plant and machinery as well as development drilling and exploration and appraisal costs. The system became a cash flow or Brown Tax for investors already in a tax-paying position. The post-tax and pre-tax internal rates of return were equal.

Later it became clear that, to facilitate the development of high cost fields, further targeted incentives were deemed necessary. Thus, over the period since 2009 a series of targeted field allowances for Supplementary Charge have been introduced for small fields, heavy oil fields, high pressure high temperature fields and those in remote locations. A specified monetary sum is allowed as a deduction against income for the tax. The effect is to increase post-tax returns in these marginal fields. The scheme recognises that, even with $100 \%$ first-year allowances, post-tax returns on high cost fields may be insufficient to meet the hurdle rates of investors.

In the UK sector many investors are not in a tax-paying position. They thus cannot take immediate advantage of the allowances noted above and are at a competitive disadvantage compared to investors who are in a full tax-paying position. In recognition of this, in 2003 an exploration /appraisal supplement was introduced which permitted unused allowances to be carried forward with interest at 6\% for 6 accounting periods. In 2006 the supplement was extended to include development costs and named the Ring Fence Expenditure Supplement. The interest rate reflects the UK Government's view of a risk free rate (3.5\% in real terms plus $2.5 \%$ for inflation). But restrictions applied such that while the total allowed period of compounding forward the allowance is 6 years for the initial expenditure the total period is reduced year by year for subsequent expenditures. Thus for expenditure in the fifth 
year compounding the allowance is only for one year. In 2012 in recognition of the fact that the rate of interest was below the weighted average cost of capital or threshold rate of investors it was increased to 10\%. The limitation on the total carry-forward period remains. However, in late 2013 in recognition of this, for onshore petroleum activities the total time period for accumulation with interest was extended to ten years. Clearly the provisions reflect the resource rent tax concept.

In sum the various elements in the UK petroleum tax system and their changes over the years reflect the need to take into account the investment hurdles of licensees. At relatively high tax rates (62\% and $81 \%$ ) it has been found that, even with $100 \%$ first-year allowances post-tax returns have been inadequate to pass the investors' hurdle rates in terms of materiality (size of NPV and NPV/I ratios) in times of capital rationing, whether they are in a tax-paying position or not. The increases in the allowances have been necessary to enable projects which are economic before tax to remain viable post-tax. This debate continues in the UK with the continued increase in costs per barrel.

In Australia, for many years there has been a resource rent tax, termed Petroleum Resource Rent Tax (PRRT) and corporate income tax applied to their continental shelf. For exploration costs the preincome tax threshold rate of return is $15 \%$ in real terms plus the Government long term bond rate. For development costs the threshold rate is $5 \%$ in real terms plus the Government long term bond rate. Exploration losses can be transferred across licence areas. In December 2009 a report entitled Australia's Future Tax System was presented to the Australian Government and published by them in 2010. It supported the resource rent tax concept but felt that specific features of the current PRRT were too generous to investors. It recommended that, in measuring economic rents, the threshold rate should be an allowance for corporate capital with the rate being equal to the long term Government bond rate. It was argued that the purpose of the interest factor was to "compensate for the market interest that the Government would have to pay for its borrowings, rather than being related to the riskiness of the project”. It followed that when there was a full loss offset the allowance for corporate capital should be the Government long term bond rate. Losses would only be refunded when a project was closed. The proposals also stated that the calculation of the base for the resource rent tax should be individual projects. Losses from one project could be transferred to other projects of an investor. When this happened the allowance for corporate capital would be set at the average corporate bond rate.

The proposals aroused much controversy, particularly over the recommendations on the threshold rates. It was argued that these did not reflect the weighted average cost of capital of the investor and that this was the relevant rate. The investments were undertaken by private sector companies and if returns reflecting their costs of capital were not available then there would be underinvestment in exploration and development. After much debate, in July 2010 the Government announced that the key existing features of the PRRT would remain and that the scope of this tax would be extended to all 
oil and gas projects both onshore and offshore with any other resource taxes being credited against the PRRT.

\section{Conclusion}

Tax systems designed on the basis that tax deductions have a higher value than they are actually given by the companies will provide incentives to underinvestment and cream skimming. The result will be lower production and a lower recovery factor, with eventual loss of government revenues. That could particularly hit measures for improved recovery from mature fields. The commitment to mature fields is time-critical - they must be upgraded before reservoir pressure falls too far and while their installations can still be used. It is also the case that the opportunity space for potential future measures to promote improved oil recovery is determined by the original development concept. Inadequate investment incentives because rates of tax-related depreciation are too low mean that new development solutions have a low level of flexibility, reducing the future recovery factor. The debate concentrates exclusively on how the companies assess tax-related depreciation over time. If theory is the prime consideration, the choice will fall on direct expensing. That is the solution for a neutral cashflow tax.

The Ministry has admitted that the tax change in the spring of 2013 was implemented without testing its effect on model fields. That is completely unacceptable, of course. Neutrality requires the internal rate of return to be the same before and after tax. In this paper, we have demonstrated that this is not the case through tax calculations for a model field representative of new developments in the Barents Sea. A nominal internal rate of return of 15.3 per cent before tax becomes only 11.2 per cent after tax with the present regime in our model project. This may be high enough to realise this project but other profitable projects before tax may not be realised. It may depend on the international oil companies changing their investment models according to the wishes of the Norwegian Minstry of Finance. While we are waiting for Godot, time-critical upgrades on mature fields are in danger of being unrealised.

In the model case, the companies could reject a project with NPVs before tax of USD 4 billion (nine per cent discounting) and USD 10.7 billion (four per cent discounting). The socioeconomic value is surely higher than 4 billion, since spin-offs for other licences in the area are not included in the project assessment. It can be argued that an 11.3 per cent return for the oil companies should be sufficient. With expertise and capital in short supply, however, the project must compete with developments in other producer countries. The government must accept company practice if it wants to ensure the realisation of improved recovery projects and bridgehead investments with big infrastructure costs in 
new areas. Today's tax regime represents a problem even on very profitable fields, since dimensioning is influenced in the direction of simple and fairly inflexible developments with a low recovery factor.

It will not be possible to find acceptance among companies in the petroleum sector that taxation is risk-free. Empirically, tax deductions are discounted by the ordinary calculation factor. Despite being aware of this, the Ministry assumes that the companies regard tax deductions as risk-free. By applying a valuation method which does not accord with company practice, the Ministry has decided that uplift should be reduced. In the real world, this change incentivises underinvestment. It can particularly affect improved recovery measures on mature fields, which have broad political support. The commitment to mature fields is time-critical - they must be upgraded before reservoir pressure sinks too far and while facilities can still be utilised.

As in all principal-agent theory, the agent may have incentives to report strategically. Where conventional NPV analyses are concerned, the companies may have private information on the required rate of return and can in principle achieve information rent through strategic reporting (excess reporting of the required rate of return). We can also conceive of a game over the information rent related to the choice of decision method. But this is not straightforward. A number of conditions must be fulfilled. It could be strategic for the oil companies to say that they use the conventional NPV method rather than partial discounted cash flow analysis if we assume that all the following conditions apply for the companies: 1) they use partial discounted cash flow analysis, 2) The government is unable to elicit the companies' actual investment appraisal method, 3) the companies separate out tax deductions as a separate partial discounted cash flow, 4) they regard tax deductions as risk-free regardless of empirical data to the contrary, 5) in conflict with economic theory, they refrain from upgrading risk for the residual cash flow. None of these conditions apply.

The debate focuses exclusively on how the companies assess tax-related depreciation into the future. If theory is the prime consideration, the answer for neutral taxation of cash flow is direct expensing. Uplift has been introduced to compensate for the postponement of tax-related depreciation, and would not be required were direct expensing permitted. The discussion is then over and the necessary calm can be achieved on the petroleum tax issue.

\section{References}

Australia's Future Tax System 2010, Final Report to the Treasurer, December 2009, Commonwealth of Australia, Canberra.

Boston Consulting Group (2007), “E\&P Investment Criteria and methodologies. Benchmarking results". 
Brealey, R A, Myers, S C, and Allen, F (2008), Principles of Corporate Finance, New York: McGraw-Hill, 9th edition.

Emhjellen, M, and Alaouze, C M (2002), "Project Valuation When There are Two Cashflow Streams”, Energy Economics, vol 24, September, 455-467.

Emhjellen, M, and Osmundsen, P (2011), "Separate cash flow valuation - Applications to investment decisions and tax design”, International Journal of Global Energy Issues 35, 43-63.

Fane, G (1987). “Neutral taxation under uncertainty”, Journal of Public Economics 33, 95-105.

Garnaut, R. and Clunies Ross, A. 1975, 'Uncertainty, risk aversion and the taxing of natural resource projects’, Economic Journal, vol. 85, pp. 272-87.

Carnaut, R. and Clunies Ross, A. 1983, Taxation of Mineral Rents, Clarendon Press, Oxford

Gillard, J., Swan, W. and Ferguson, M. 2010, 'Breakthrough agreement with industry on improvements to resources taxation', Statement by the Prime Minister, Deputy Prime Minister and Treasurer, and Minister for Resources and Energy, 2 July, viewed September 2010, http://www.pm.gov.au/node/6868.

Ministry of Finance, Norway (2013),“Riktige beregninger fra Finansdepartementet”, internet document, 21 June, accessible at http://www.regjeringen.no/nb/dep/fin/aktuelt/nyheter/2013/riktigeberegninger-fra-finansdepartemen.html.

Johnston, D (2008), “Changing Fiscal Landscape”, Journal of World Energy Law \& Business 1, 1, 3154.

Laughton, D G (1998), "The potential for use of modern asset pricing methods for upstream petroleum evaluation: Introductory remarks”, Energy Journal 19, 1-11.

Lewellen, W G 1977, “Some Observations on Risk-Adjusted Discount Rates”, Journal of Finance, vol 32, 1331-1337.

Osmundsen, P (2013), “Økt oljeutvinning fra eksisterende felt - Beslutningskriterier og innovasjon på norsk sokkel”, Magma, Tidsskrift for økonomi og ledelse, no 03/13, 56-66.

Osmundsen, P (2005), “Optimal Petroleum Taxation - Subject to Mobility and Information Constraints”, in Glomsrød, S, and Osmundsen, P, eds., Petroleum Industry Regulation within Stable States. Recent Economic Analysis of Incentives in Petroleum Production and Wealth Management, Ashgate Studies in Environmental and Natural Resource Economics, Ashgate Publishers.

Osmundsen, P (2013), “Choice of Development Concept - Platform or Subsea Solution? Implications for the Recovery Factor”, Oil \& Gas Facilities (Society of Petroleum Engineers), October 2013, vol 2, no 5, 64-70.

Osmundsen, P, and Johnsen, T (2013), “Avskrivninger - Teori og virkelighet”, Samfunnsøkonomen, no 5, 2013, 14-22.

Summers, L. H. (1987), "Investment incentives and the discounting of depreciation allowances," in M. Feldstein (Ed.), The effects of Taxation on Capital Accumulation, University of Chicago Press, Chicago, s. 295-304. 


\section{Appendix: simplified calculation for a model field}

Unless otherwise specified, all monetary values in this appendix are in Norwegian kroner (NOK).

A special petroleum tax is levied on profits from petroleum production and pipeline transport on the NCS, currently at a rate of 51\%. It is applied to relevant income in addition to the standard $27 \%$ corporation tax to produce a $78 \%$ marginal tax rate on income subject to the petroleum tax regime. The basis for computing the special petroleum tax is the same as for income subject to ordinary corporation tax, except that losses incurred on land are not deductible from the special petroleum tax and that a tax-free allowance, or uplift, is granted at a rate of 5.5\% per year. The uplift is computed on the basis of the original capitalised cost of offshore production installations, and may be deducted from taxable income for a period of four years, starting in the year in which the capital expenditure is incurred. Unused uplift may be carried forward indefinitely. The maximum rate of depreciation for development costs related to offshore production installations and pipelines is $16.67 \%$ per year. Depreciation starts when the cost is incurred. Exploration costs may be deducted in the year they are incurred. Any tax losses may be carried forward indefinitely against subsequent income earned.

As an illustration in this appendix, we will use a simplified calculation involving 60 million in investment and 70 million of income, both occurring in year 1, and we assume cash flow taxation. Beta is assumed to be 0.83 for net cash flow after tax without debt financing (100\% equity). The risk-free interest rate and the risk premium are assumed to be $4 \%$ and $6 \%$ respectively, making the required rate of return 9.00\% [4\%+0.83x6\%]. Net cash flow before and after tax is then 10 million and $10 x(1-0.78)=2.2$ million respectively, and NPV after tax is $2.2 /(1+0.09)=2.02$ million.

If we assume that the project must have the same market value even if we use partial cash flow discounting, and divide the project into two different cash flows, we can establish two different models. In the first of these, which is the company practice, post-tax income is proportionate to the marginal tax rate and tax deductions relate to the investment (method 1). The other, which forms the basis for the Ministry of Finance, involves separate assessment of tax deductions for investment while post-tax income plus pre-tax investment form the uncertain cash flow (method 2). This gives the following table (table 1).

Table 1 


\begin{tabular}{|l|c|c|}
\hline & & Year \\
\hline Partial cash flow discounting & NPV & 1 \\
\hline Post-tax income & 14.71 & 15.4 \\
\hline Post-tax investment & $(12.69)$ & $(13.2)$ \\
\hline Post-tax cash flow & 2.02 & 2.2 \\
\hline Assuming we use the Ministry’s calculation example & \\
\hline Uncertain post-tax cash flow & $(42.98)$ & $(44.6)$ \\
\hline Secure post-tax cash flow & 45.00 & 46.8 \\
\hline Post-tax cash flow & 2.02 & 2.2 \\
\hline
\end{tabular}

The NPV of the secure cash flow - or the cash flow without systematic risk - when this is assumed in method 1 can be calculated with a risk-free discount rate of $4 \%$. Since we know the NPV of the project (2.02) and now the NPV of the "secure" cash flow, we also know the NPV of the uncertain cash flow. This gives an implicit risk-adjusted required rate of return for the uncertain cash flow. With method 1 , we obtain $15.4 /(1+a)=14.71$, which gives $a=4.69 \%$. With method 2 , we get $44.6 /(1+a)=-42.98$, giving $a=3.77 \%$. With these required rates of return, the betas for the uncertain cash flow are 0.11 and -0.04 for methods 1 and 2 respectively. Since the beta for the net cash flow is a value-weighted average of the two betas, we have:

Method 1: 0.11 x 14.71/2.02 0 x (-12.69/2.02) $=0.83$

Method 2: -0.04 x $-42.98 / 2.02+0$ x $(45.0 / 2.037)=0.83$

It is worth noting that the "uncertain" cash flow in method 2, with a negative beta, must be valued at a required rate of return below the risk-free discount rate. For all the cash flows in period 1, it can be shown - as above - that the beta is a value-weighted average of the betas for the two cash flows. This does not work in a multiperiod model with varying weightings in different periods. But we can still calculate implicit required rates of return and then the implicit beta for the uncertain cash flow. With our project and the new tax rules, we obtain table 2 .

Table 2

\begin{tabular}{|l|l|l|l|l|l|l|l|}
\hline Partial cash flow discounting & NPV & 1 & 2 & 3 & 4 & 5 & 6 \\
\hline
\end{tabular}




\begin{tabular}{|l|c|c|c|c|c|c|c|}
\hline Post-tax income & 10.22 & 15.4 & 0 & 0 & 0 & 0 & 0 \\
\hline Post-tax investment & $(10.69)$ & $(50.517)$ & 9.483 & 9.483 & 9.483 & 7.8 & 7.8 \\
\hline Post-tax cash flow & $(0.47)$ & $(35.117)$ & 9.483 & 9.483 & 9.483 & 7.8 & 7.8 \\
\hline Assuming we use the Ministry's calculation example \\
\hline Uncertain post-tax cash flow & $(47.47)$ & $(44.6)$ & & & & & \\
\hline Secure post-tax cash flow & 47.00 & 9.483 & 9.483 & 9.483 & 9.483 & 7.8 & 7.8 \\
\hline Post-tax cash flow & $(0.47)$ & $(35.117)$ & 9.483 & 9.483 & 9.483 & 7.8 & 7.8 \\
\hline
\end{tabular}

The NPV after tax has declined because we have used the actual depreciation period in the tax rules. The implicit required rate of return for post-tax income in method 1 is $50.67 \%$, and the beta for post-tax income is then 7.78. With method 2, the required rate of return for the uncertain cash flow and the beta are both negative at $6.05 \%$ and 1.67 respectively.

Should the companies use the Ministry's model (model 2), this must be taken to mean that they make major investments in oil and gas projects on the basis of the value of the secure deductions and despite the strongly negative value of the uncertain cash flow. It is possible, of course, to farm into a field on the NCS with uncertain tail production, for example, but no remaining value from tax deductions. According to model 2 (the Ministry), the companies will be willing to pay more for this uncertain cash flow than the sum of the expected cash flow (a required rate of return which is negative at 6.05\% in the example). We do not believe this to be the case, and see no transaction value which might suggest it. Nor do we see any method for identifying a sensible required rate of return which can value the very negative uncertain cash flow.

In method 1, because the present value of the secure tax deductions has increased and reduced the NPV of after tax costs, the required rate of return for post-tax income must increase substantially (50.67\%) for the project to have the same NPV. This appears consistent given that the risk for the residual discounted cash flow must rise if a secure element is removed from one cash flow.

If we drop the assumption that the project should have the same NPV as it does when discounting the net cash flow after tax (value additivity), utilise risk-free discounting for the "secure" cash flow and apply the required rate of return to the net cash flow after tax (9\%) in order to value the "uncertain" cash flow, we get results like those in table 3.

Table 3 


\begin{tabular}{|l|c|c|c|c|c|c|c|}
\hline $\begin{array}{l}\text { Partial cash flow } \\
\text { discounting }\end{array}$ & NPV & 1 & 2 & 3 & 4 & 5 & 6 \\
\hline Post-tax income & 14.13 & 15.4 & 0 & 0 & 0 & 0 & 0 \\
\hline Post-tax investment & $(10.69)$ & $(50.517)$ & 9.483 & 9.483 & 9.483 & 7.8 & 7.8 \\
\hline Post-tax cash flow & 3.43 & $(35.117)$ & 9.483 & 9.483 & 9.483 & 7.8 & 7.8 \\
\hline Assuming we use the Ministry’s calculation example \\
\hline Uncertain post-tax cash flow & $(40.92)$ & $(44.6)$ & & & & & \\
\hline Secure post-tax cash flow & 47.00 & 9.483 & 9.483 & 9.483 & 9.483 & 7.8 & 7.8 \\
\hline Post-tax cash flow & 6.08 & $(35.117)$ & 9.483 & 9.483 & 9.483 & 7.8 & 7.8 \\
\hline
\end{tabular}

The NPV of the project has apparently increased with both methods. The required rate of return for net cash flow after tax applied for post-tax income in method 1 is substantially lower than is implicit in table 2, and apparently gives the project a NPV of 3.43 million after tax. For method 2, the net NPV is 6.08. The negative "uncertain” cash flow now has a smaller negative NPV (discounted with the required rate of return for net cash flow). We have no confidence in any of these NPVs. Only one market value exists for a project, and we believe that the companies' decision criteria based on the required rate of return for net cash flow is the method which estimates this best. If one maintains value additivity, the method of calculating value cannot, as in table 3, change the estimate of the project's market value.

\section{$\underline{\text { Model field }}$}

The model field has a total output of 78 million standard cubic meters over 28 years and overall investment of 15.67 billion USD over 10 years (in 2014 money). We assume an oil price of USD 90 per barrel in 2014 value and a nominal required rate of return of $9 \%$ on net post-tax cash flow. Table 4 presents the calculations in three parts - first the normal valuation method with discounting of net cash flows in the top section, then the Ministry's proposed partial discounted cash flow method in section 2, and finally the method based on a division between post-tax income/operation and post-tax investment. With the new tax rules, table 4 shows that the project has a post-tax NPV of 769 million USD and an internal rate of return of $11.3 \%$. The internal rate of return before tax is $15.3 \%$. With a cash flow tax, the internal rate of return would also have been $15.3 \%$ after tax. The tax system cannot then be described as neutral. 
Table 4 Economics of model field

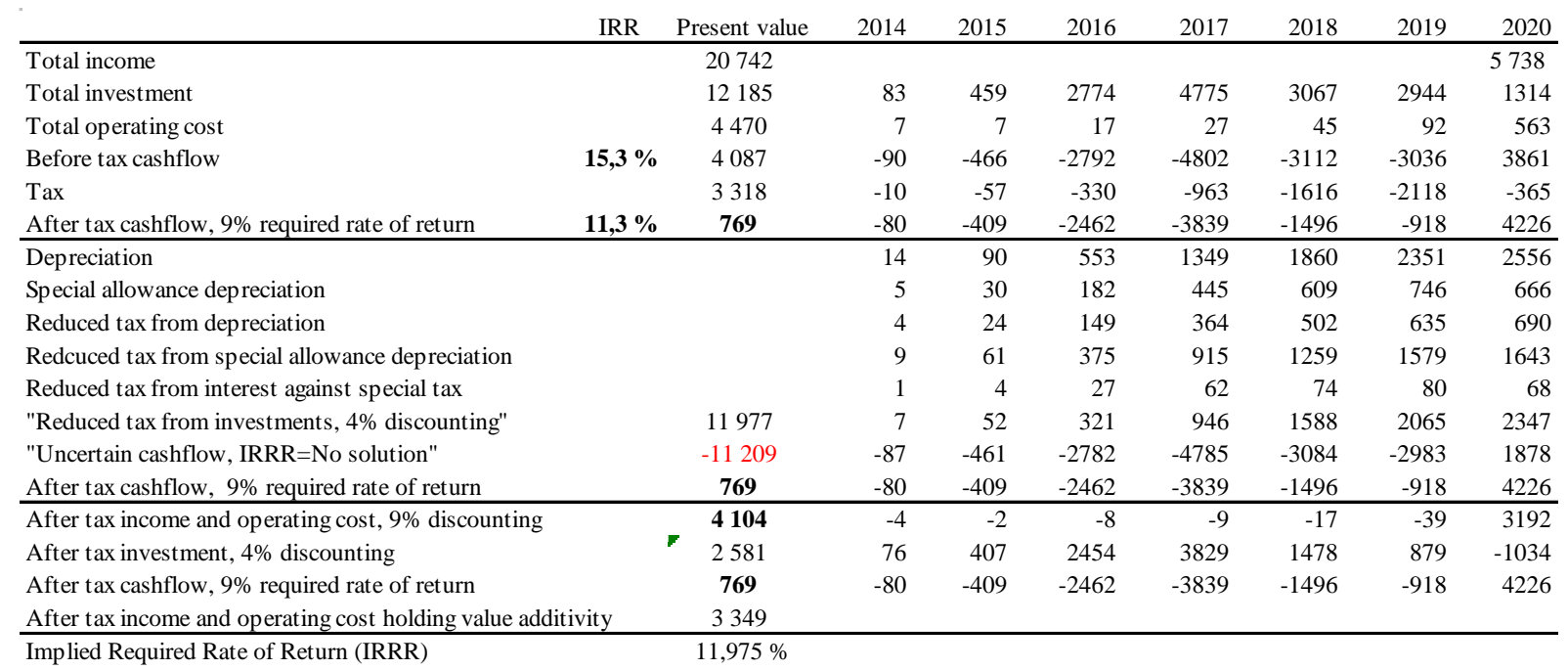

\begin{tabular}{rrrrrrrrrrrrr}
2021 & 2022 & 2023 & \multicolumn{1}{c}{2024} & 2025 & 2026 & 2027 & 2028 & 2029 & 2030 & 2031 & 2032 \\
\hline 6503 & 6633 & 5412 & 4140 & 2815 & 2226 & 2050 & 1793 & 1600 & 1477 & 1268 & 1294 \\
574 & 488 & 498 & 0 & 0 & 0 & 0 & 0 & 0 & 0 & 0 & 0 \\
574 & 586 & 598 & 609 & 622 & 634 & 647 & 660 & 673 & 686 & 700 & 714 \\
5354 & 5559 & 4317 & 3531 & 2194 & 1591 & 1404 & 1133 & 927 & 790 & 568 & 579 \\
1991 & 2586 & 2663 & 2222 & 1624 & 1163 & 994 & 892 & 771 & 670 & 530 & 448 \\
3363 & 2972 & 1654 & 1309 & 570 & 428 & 410 & 241 & 156 & 120 & 38 & 132 \\
\hline 2575 & 2194 & 1481 & 970 & 479 & 260 & 164 & 83 & 0 & 0 & 0 \\
434 & 293 & 158 & 86 & 54 & 27 & 0 & 0 & 0 & 0 & 0 \\
695 & 592 & 400 & 262 & 129 & 70 & 44 & 22 & 0 & 0 & 0 \\
1535 & 1268 & 836 & 538 & 272 & 147 & 84 & 42 & 0 & 0 & 0 \\
47 & 30 & 20 & 10 & 5 & 3 & 1 & 0 & 0 & 0 & 0 \\
2339 & 2084 & 1573 & 1033 & 608 & 313 & 174 & 97 & 32 & 0 & 0 \\
1024 & 888 & 81 & 276 & -39 & 115 & 236 & 144 & 124 & 120 & 38 & 132 \\
3363 & 2972 & 1654 & 1309 & 570 & 428 & 410 & 241 & 156 & 120 & 38 & 132 \\
\hline 1598 & 1377 & 579 & 276 & -39 & 115 & 236 & 144 & 124 & 120 & 38 & 132 \\
-1765 & -1596 & -1075 & -1033 & -608 & -313 & -174 & -97 & -32 & 0 & 0 \\
3363 & 2972 & 1654 & 1309 & 570 & 428 & 410 & 241 & 156 & 120 & 38 & 132 \\
& & & & & & & & & 0 \\
\hline
\end{tabular}

\begin{tabular}{|c|c|c|c|c|c|c|c|c|c|c|c|c|c|c|}
\hline 2033 & 2034 & 2035 & 2036 & 2037 & 2038 & 2039 & 2040 & 2041 & 2042 & 2043 & 2044 & 2045 & 2046 & 2047 \\
\hline 1237 & 1178 & 1115 & 1050 & 1071 & 911 & 929 & 947 & 966 & 887 & 905 & 820 & 837 & 853 & 762 \\
\hline 0 & 0 & 0 & 0 & 0 & 0 & 0 & 0 & 0 & 0 & 0 & 0 & 0 & 0 & 0 \\
\hline 728 & 743 & 758 & 773 & 788 & 804 & 820 & 809 & 797 & 783 & 770 & 755 & 739 & 722 & 641 \\
\hline 509 & 435 & 358 & 277 & 283 & 106 & 108 & 138 & 170 & 104 & 135 & 66 & 98 & 131 & 121 \\
\hline 424 & 368 & 309 & 248 & 218 & 152 & 84 & 96 & 120 & 107 & 93 & 78 & 64 & 89 & 98 \\
\hline 84 & 67 & 49 & 30 & 64 & -45 & 25 & 42 & 50 & -3 & 42 & -13 & 34 & 42 & 23 \\
\hline 0 & 0 & 0 & 0 & 0 & 0 & 0 & 0 & 0 & 0 & 0 & 0 & 0 & 0 & 0 \\
\hline 0 & 0 & 0 & 0 & 0 & 0 & 0 & 0 & 0 & 0 & 0 & 0 & 0 & 0 & 0 \\
\hline 0 & 0 & 0 & 0 & 0 & 0 & 0 & 0 & 0 & 0 & 0 & 0 & 0 & 0 & 0 \\
\hline 0 & 0 & 0 & 0 & 0 & 0 & 0 & 0 & 0 & 0 & 0 & 0 & 0 & 0 & 0 \\
\hline 0 & 0 & 0 & 0 & 0 & 0 & 0 & 0 & 0 & 0 & 0 & 0 & 0 & 0 & 0 \\
\hline 0 & 0 & 0 & 0 & 0 & 0 & 0 & 0 & 0 & 0 & 0 & 0 & 0 & 0 & 0 \\
\hline 84 & 67 & 49 & 30 & 64 & -45 & 25 & 42 & 50 & -3 & 42 & -13 & 34 & 42 & 23 \\
\hline 84 & 67 & 49 & 30 & 64 & -45 & 25 & 42 & 50 & -3 & 42 & -13 & 34 & 42 & 23 \\
\hline 84 & 67 & 49 & 30 & 64 & -45 & 25 & 42 & 50 & -3 & 42 & -13 & 34 & 42 & 23 \\
\hline 0 & 0 & 0 & 0 & 0 & 0 & 0 & 0 & 0 & 0 & 0 & 0 & 0 & 0 & 0 \\
\hline 84 & 67 & 49 & 30 & 64 & -45 & 25 & 42 & 50 & -3 & 42 & -13 & 34 & 42 & 23 \\
\hline
\end{tabular}


With the Ministry's method, the NPV of the uncertain cashflow needs to be a negative 11.209 billion USD to hold value additivity. This implies that the companies will have to be willing to invest in this project on the basis of the value of the secure deductions. In addition, a discount rate that gives the NPV of the uncertain cashflow of 11.209 cannot be found. There is no solution as shown in figure 1 .

Figure 1. NPV of "uncertain cashflow" at different discount rates

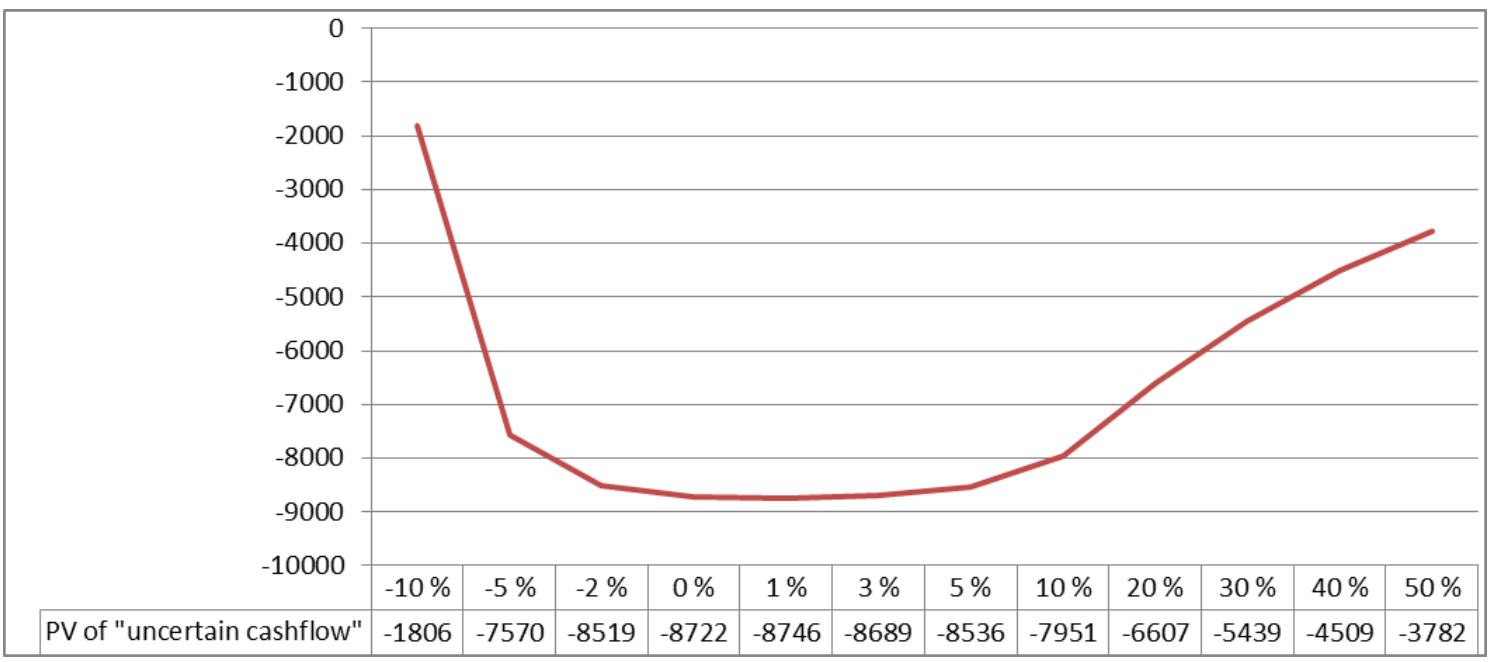

The NPV of the "uncertain cashflow" never falls below negative 9 billion USD, far from the necessary negative -11.209 billion in order to achieve value additivity. The method makes no practical sense.

Valuing post-tax investment with a risk-free discount rate of $4 \%$ indicates that the implicit discounting of the "uncertain" cash flow must rise to $11.975 \%$ if the project is to have the same total NPV after tax (769 million USD). An erroneous discounting of this cash flow by $9 \%$ would give the impression that the project now has a value of 1.523 billion USD after tax. A reduction in uplift to just $2 \%$ would mean a substantial decline in the post-tax profitability of the project, as shown in table 5. 
Table 5

\begin{tabular}{lcc} 
& IRR & Present value \\
\hline Total income & 20742 \\
Total investment & 12185 \\
Total operating cost & 4470 \\
Before tax cashflow & 4087 \\
Tax & $\mathbf{1 5 , 3} \%$ & 4370 \\
After tax cashflow, 9\% required rate of return & $\mathbf{- 2 8 3}$ \\
\hline Depreciation & \\
Special allowance depreciation & \\
Reduced tax from depreciation & \\
Redcuced tax from special allowance depreciation & \\
Reduced tax from interest against special tax & \\
"Reduced tax from investments, 4\% discounting" & 10603 \\
"Uncertain cashflow, IRRR=No solution" & -10886 \\
After tax cashflow, 9\% required rate of return & -283 \\
\hline After tax income and operating cost, 9\% discounting & $\mathbf{4 1 0 4}$ \\
After tax investment, 4\% discounting & 3955 \\
After tax cashflow, 9\% required rate of return & $-\mathbf{2 8 3}$ \\
After tax income and operating cost holding value additivity & 3672 \\
\hline Implied Required Rate of Return (IRRR) & $11,020 \%$
\end{tabular}

The project now has a negative NPV of -283 million USD after tax (8.2\%) internal rate of return). The government could then find that the companies will reject a project with a pre-tax NPV of more than 4 billion USD. 